\title{
Stefan Nehring \\ Four arguments why so many alien species settle into estuaries, with special reference to the German river Elbe
}

Received: 26 April 2005 / Accepted: 3 September 2005/Published online: 2 February 2006

(C) Springer-Verlag and AWI 2006

\begin{abstract}
In one of the largest European rivers, the Elbe, from its source in the Czech Republic to the German North Sea, 31 alien macrozoobenthic species have been recorded in total. Most of these species have been introduced by shipping activities. With a total number of 21 species, many of the established aliens occur - partly exclusively - in the brackish area of the Elbe estuary. In order to explain this observed settlement characteristic, four main arguments come into consideration: (1) estuaries with intensive international shipping have a higher potential infection rate than other aquatic zones; (2) brackish water species have, due to specific physiological characteristics, a better chance of being transported alive than euhaline or freshwater species and they also probably have a higher perennation and establishment potential after release; (3) brackish waters have the greatest natural 'indigenous species minimum', so that more alien species can potentially establish; and (4) salt-tolerant limnetic alien species introduced into inland water reached the coast at first in the estuaries. It seems that the combination of brackish water with its unsaturated ecological niches and intensive international ship traffic has the highest potential infection rate for aquatic systems with alien macrozoobenthic species. And, estuaries are subjected to a two-sided invasion pressure by alien species, via the ocean (mainly shipping) and via inland waters (mainly shipping canal construction). The identification of such patterns is an important prerequisite for the development of a forward-looking alien monitoring and management strategy.
\end{abstract}

Communicated by K. Reise

S. Nehring

AeT umweltplanung, Bismarckstraße 19, 56068 Koblenz, Germany E-mail: nehring@aet-umweltplanung.de

Tel.: +49-261-1330398

Fax: + 49-261-1330399
Keywords Introduced species - Macrozoobenthos · Elbe estuary · Establishment · Management

\section{Introduction}

A side-effect of the globalization of trade is the introduction of species into habitats outside their native geographical range. Several of these alien species exert a significant impact upon community structure and functions, by modifying spatial and food chain resources, and with direct or indirect effects on the occurrence of indigenous species (Drake et al. 1989; Leppäkoski et al. 2002). In addition to the ecological risks, the authors pose that alien species are of increasing importance in a more and more 'borderless' world within economic interests and conservation efforts. In recent years, national and international environmental policy and legislation have begun to reflect this fact (e.g. CBD 1992; IMO 2004). A basic requirement for a proper processing of measures which can lead to a minimization of maninduced spreading of species, is a comprehensive analysis of the phenomenon 'bioinvasion'.

The occurrence of alien species has been recognized most frequently for terrestrial environments (Drake et al. 1989), however, since several decades it becomes clear that alien species have also become dominant members of several food webs in marine and inland waters (e.g. Sandlund et al. 1999; Leppäkoski et al. 2002). Estuaries have been especially common sites of invasions worldwide (e.g. Ruiz et al. 1997; Cohen and Carlton 1998), a phenomenon also recorded from European waters (Wolff 1999; Paavola et al. 2005). Based on studies on aquatic habitats in the Netherlands, Wolff (1999) formulated three main hypotheses to explain the high numbers of alien macroinvertebrate species in Dutch estuaries. On the basis of a comprehensive analysis with special reference to the spatial distribution of the macrozoobenthos in the second largest river in Germany, the Elbe, these theses were tested. In addition, it was also proved whether 
also further arguments should be taken into consideration.

\section{Methods}

\section{Study site}

The Elbe River (Czech Labe, German Elbe) is one of the largest rivers in central Europe. It rises in the Czech Repulic in the Riesengebirge (Giant Mountains) at an altitude of about $1,400 \mathrm{~m}$. Shortly after crossing the Czech-German border and passing through the sandstone defiles, the stream assumes a north-westerly direction, traversing a large portion of Germany before emptying into the North Sea. In total, the Elbe is about $1,091 \mathrm{~km}$ long and moves volumes of water typically ranging from $150 \mathrm{~m}^{3} / \mathrm{s}$ in its upper length to around $300 \mathrm{~m}^{3} / \mathrm{s}$ at the Czech-German border and $870 \mathrm{~m}^{3} / \mathrm{s}$ near its mouth at Cuxhaven. The course of the Elbe is distinguished in six main hydrogeographical sections (headwater region, Bohemian Elbe, upper and middle Elbe, estuary, open German Bight), with up to four subsections each (Table 1, Fig. 1). The Elbe is one of the major waterways of central Europe and is connected to many parts of southern and eastern Europe via an extensive network of shipping canals.

Data

The study is confined to the macroinvertebrate species occurring in the sediments and on artificial hard bottoms of the river Elbe, from its source to the German Bight. Most of the faunistic data are derived either from published reports and articles, or from unpublished surveys which were carried out for the purpose of water quality reports. Main data sources were comprehensive macrozoobenthos surveys and monitoring programmes carried out primarily by the German institutions, ARGE Elbe in Hamburg and the Federal Institute of Hydrology in Koblenz, in part in cooperation with the Czech T.G. Masaryk Water Research Institute in Prague (Key references are given in Table 1).

In the investigations, common macroinvertebrate sampling methods have been applied. In the freshwater region different techniques, such as artificial substrates, nets, dredges, cores and grabs were used individually or in combination. Sampling was performed either from banks, boats or diving bells (Tittizer et al. 1988), permanent benthic fauna was also collected by hand from the surface of stones used as embankments (Schöll and Fuksa 2000). In 1995, the Federal Institute of Hydrology in Koblenz has initiated a macrozoobenthos monitoring programme in all German North Sea estuaries, which is part of the Trilateral Monitoring and Assessment Programme of the Wadden Sea (TMAP). Samples are usually collected once a year during fall season. In the Elbe estuary, six subtidal stations are monitored along a transect parallel to the waterway from the upper brackish water border to the polyhaline milieu. At each station six replicates were usually collected using a vanVeen grab $\left(0.1 \mathrm{~m}^{2}\right)$ and a dredge haul was taken (Nehring and Leuchs 1999).

\section{Definitions}

The expanding study on alien species resulted in a surfeit of specialized terms, liable to misapplication and error. Terms and definitions used in this study are based on the Convention on Biological Diversity (CBD 1992, 2000):

Alien species - a species, subspecies, or lower taxon introduced outside its normal past or present distribution.

Established alien species - an alien species that is reproducing in the wild and has established a durable population in an area.

Invasive alien species - an alien species whose establishment and spread threaten ecosystems, habitats or species with economic or environmental harm.

Introduction - the movement, by human agency, of a species, subspecies, or lower taxon outside its natural range (past or present)

\section{Results}

The amount of alien taxa assumed to have been established in the macrozoobenthos of German inland and coastal waters of the North and Baltic Sea recently reached a number of 63 species. Especially for the Elbe, from its source to its outer estuary including the full marine milieu of the open German Bight, in total 31 alien macrozoobenthic species have been identified as occurring in self-sustaining populations today (Table 1). The largest taxonomic group in the Elbe are crustaceans (12 alien species), followed by bivalves (eight alien species). It is noticeable that certain ecologically important groups, such as Insecta (especially Chironomidae) for freshwater habitats and Oligochaeta for freshwater, brackish and marine habitats, lack representatives among the introduced species reported for German waters (the only exception is the Oligochaete Branchiura sowerbyi). This is probably related to problems in identification.

Many of the alien macrozoobenthic species in the Elbe are at least locally abundant and about every second alien species has already spread successfully across a larger area (Table 1). While many species seem to remain insignificant additions to the indigenous biota, every third alien species may be regarded as invasive in the Elbe river. However, even if displacement of indigenous species by aquatic aliens is sometimes suggested, only decreased abundances but no extinctions of indigenous species have been documented in German waters so far.

From the headwater region up to the German Bight, major natural hydrographical and topograhical differ- 


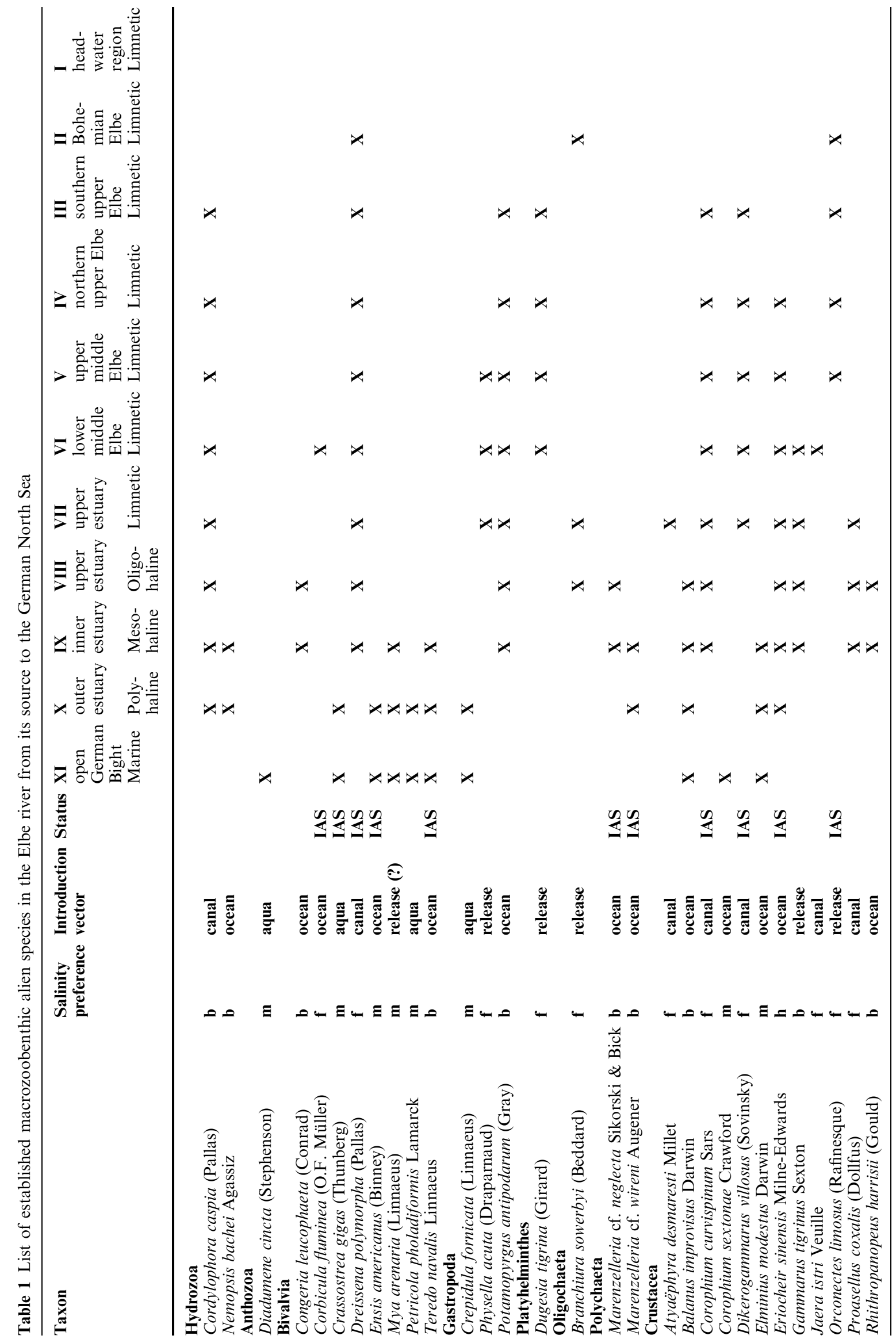




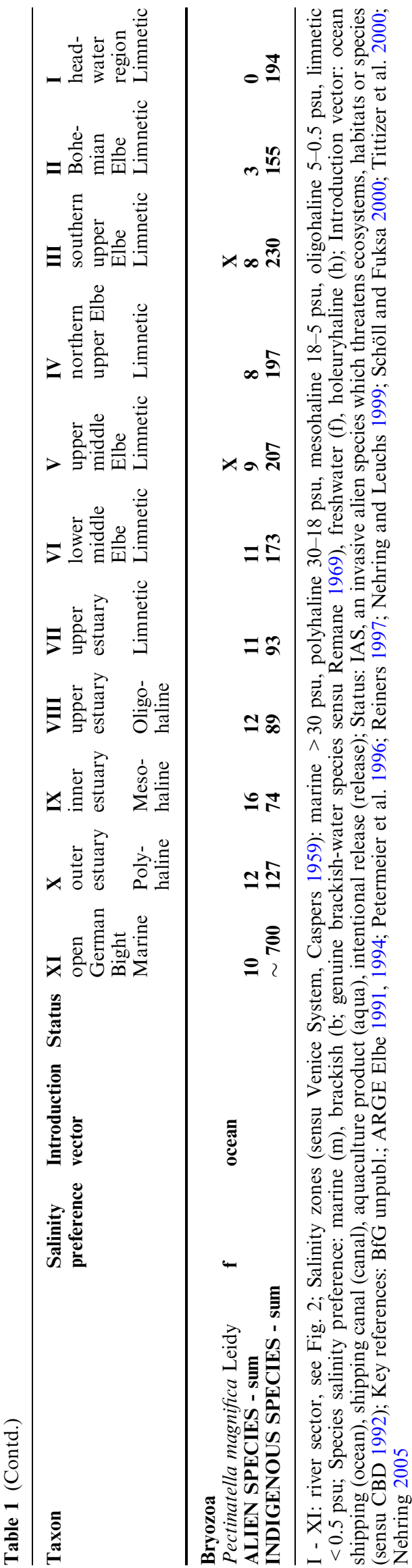

ences exist, which is also reflected in a distinct occurrence of alien species. In addition to pollution of water and sediments as well as engineering impacts (damming, stream straightening, deepening, dredging and dumping), another fundamental factor for the occurrence of organisms is the changing hydrological regime. Highly variable water runoff in the stream and, especially on the North Sea coast, the tide with all its consequences (development of eulittoral areas and variable freshwaterseawater interfaces) play an important role for the establishment of permanent populations of macroinvertebrate species. Due to these specific characteristics and wide range of opportunities, generalists should have the best chance for settlement. Among the aliens established in German waters and especially in the Elbe, euryoecious and potent competitors predominate consequently. Only in the headwater region of the Elbe no alien species have been observed so far. This might be due to the fact that this region is relatively undisturbed by anthropogenic activities, such as shipping, commercial fisheries or direct connections to canals.

In the Elbe, most of the known introduced macroinvertebrate species have established permanent populations in the saltwater influenced area of the estuary as well (21 species in total; Table 1). Both downstream in fully marine waters, and upstream, their number is clearly lower. In addition, the share of the alien species compared to the respective total indigenous macrozoobenthic species numbers amounts to $1 \%$ in the open German Bight, about $20 \%$ in the mesohaline zone, and only $6 \%$ in the limnetic non-tidal zone of the Elbe (Table 1).

\section{Discussion}

As species introductions are irreversible, the extension of their distribution area and increase in abundance is an ongoing process. The ecological consequences which arise for the biocoenoses as well as the scale on which the biodiversity is modified is not analyzed, understood or evaluated in detail yet (e.g. Reise et al. 2002; Nehring 2005). But it is apparent that the introduction of alien species enhances the trend of global unification of flora and fauna associated with an irretrievable loss in biodiversity (CBD 2000). A comprehensive analysis of the establishment mechanisms of alien species is one of several basic requirements for management strategies that could lead to a reduction of anthropogenic dispersal and impacts of species.

The relationship between salinity and species number is well known, since in contrast to freshwater and seawater, brackish waters are characterized by the lowest number of indigenous species (Artenminimum sensu Remane 1934). On account of this worldwide valid fact, one could expect that the number of established alien species in estuarine waters remains low as well. However, such an expectation has to be rejected. Among aquatic environments, estuaries have been common sites of biological invasions worldwide (e.g. Ruiz et al. 1997; 


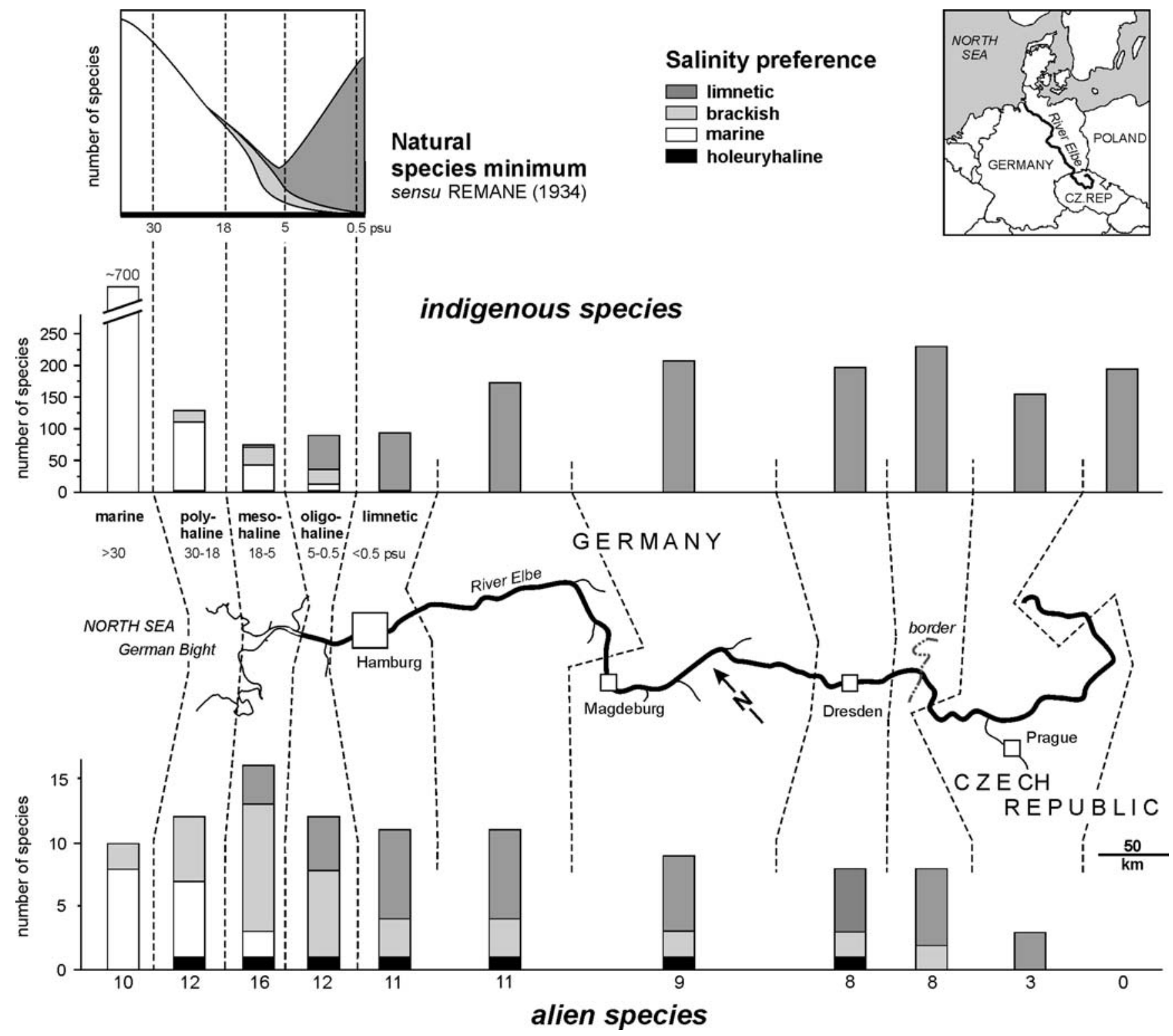

Fig. 1 Species number and salinity preference of indigenous and alien macrozoobenthic species in the Elbe river, from its source in the Czech Republic to the German North Sea

Cohen and Carlton 1998). It was shown for Dutch (Wolff 1999) as well as for German waters (this study) that the brackish areas of estuaries have been invaded more frequently than rocky or sandy shores of the outer coast as well as inland waters by alien macroinvertebrate species. The question arises what explains the observed pattern. Wolff (1999) formulated three main hypotheses for Dutch waters. In the following with reference to the Elbe, his theses are tested, partly modified and complemented with one further thesis:

First argument: location of ports

In his first hypothesis Wolff (1999) stated that the observed high numbers of alien macroinvertebrate species in Dutch estuaries reflects the location of major ports there (Rotterdam, Antwerp). The same goes in German North Sea estuaries which are characterized by intensive international ocean shipping. During the period from 1995-1999, a total of almost 800,000 commercial ship movements were registered in the German North Sea (excluding ferries) (Reineking 2005). The biggest German port, Hamburg, is located in the tidal area of the Elbe. In 2002, the seven main ports at the German North Sea coast had a total volume turnover of about 176 million tons, with about 87 alone at Hamburg harbour. It has been estimated that up to 4,000 pelagic and benthic species are being transported between continents by ships every day (Minchin and Gollasch 2003). Densities of organisms in the ballast water were highly variable from ship to ship ( 0 to 18,000 organisms $\mathrm{m}^{-3}$; 
Smith et al. 1999). Recent calculations by Gollasch (1996) on the individual entry by ballast water discharges from overseas areas into the coastal and especially estuarine waters of the German North Sea coast revealed that 2.7 million individuals are being released every day. Prior to the development of anti-fouling paints, most introductions of macroinvertebrates on the German North Sea coast were associated with hull fouling. Today, transportation by hull fouling and ballast water appear to be equally important (Nehring 2002). In extreme cases a macrofauna fouling coverage up to $100 \%$ could be found on ships' hulls in the North Sea today (WWF 2001). Here, non-indigenous species were recorded in $96 \%$ of all hull samples taken from worldwide operating ships at the German North Sea coast (Gollasch 2002). In this context it is not surprising that international ocean shipping represents the most important introduction vector of aquatic alien species occurring in the Elbe estuary. About half $(46 \%)$ of the 24 alien species is associated with this vector (Table 1). Combined with the facts that ballast water often has estuarine to marine character (Gollasch 1996) and hull fouling often consists of euryoecious non-freshwater species (on basis of data given by Gollasch 1996), one can assume that estuaries with intensive international ocean ship traffic have a higher potential infection rate than other coastal zones (sensu Wolff 1999) and in general inland waters.

Second argument: genuine brackish water species

The interface between marine and freshwater habitats is charaterized by an intermediate transition zone, with brackish waters and the instability of environmental factors. In this zone several species occur chiefly or exclusively and, if a species has the optimum of its vital activity in brackish water, it is defined by Remane (1969) as a genuine brackish water species. At first sight it is not obvious that a species belongs to this ecotype, however. One example is the pontocaspian hydrozoan Cordylophora caspia which occurs in relatively high abundances occasionally also in the upper reaches of rivers and inland lakes. These 'freshwater' habitats can be characterized almost without exception by ionic anomalies, however (Arndt 1984).

In rivers, from their sources to their mouths, the number of indigenous genuine brackish water species worldwide is significantly lower $(<2 \%)$ compared to the number of true marine and true freshwater species (S. Nehring, in preparation). Nevertheless, ten of the 31 alien species in the macrozoobenthos of the entire Elbe are genuine brackish-water species (Table 1), so that the share of this ecotype among the aliens is now more than twenty times higher than it was in indigenous biocoenoses. Genuine brackish water species are characterized by a high tolerance for changing environmental conditions (a.o. salinity, oxygen) and possess a high ecological adaptability (Michaelis et al. 1992; Cognetti and
Maltagliati 2000). Therefore, Wolff (1999) assumed in his second hypothesis that they have a better chance of being transported alive than euhaline or freshwater species. In addition to the statement of Wolff (1999) it seems a reasonable assumption that they also have probably a higher perennation and establishment potential after release.

Third argument: the natural species minimum

As described by Remane (1934) for the Baltic Sea, the most conspicuous 'indigenous species minimum' occurs in the Elbe estuary where salinities are 5-18 psu (mesohaline zone; Table 1). In contrast, this area is characterized by the highest number of alien macrozoobenthos species as well as by the highest percentage of alien species compared to the respective total indigenous macrozoobenthic species numbers found in Elbe waters (16 species and about $20 \%$, respectively). Both downstream in fully marine waters, and upstream, their number and their share is clearly lower. Based on data of benthic macrofauna studies from different aquatic areas in the Netherlands, Wolff (1999) showed shares of alien species in the same order of magnitude.

Wolff (1999) stated in his third hypothesis that the natural species minimum in brackish waters (sensu Remane 1934) unsaturated with ecological niches is of considerable importance to the establishment of alien species. As Wolff (1999) pointed out, it will be difficult to test this hypothesis but on the other hand we have no arguments to contradict. For the Elbe estuary it seems that the macroinvertebrate community of mixed indigenous and alien organisms in many respects resembles co-evolved assemblages. Empty niches, however, seem to be an essential basis for this. In former times, for instance, no species of barnacles, crabs and filter-feeding molluscs occurred in the oligo-mesohaline zone of tidal waters in North-western Europe (e.g. Wolff 1999). Nowadays, the alien barnacles Balanus improvisus and Elminius modestus, the alien crabs Eriocheir sinensis and Rhithropanopeus harrisii, and several alien bivalves (e.g. Congeria leucophaeta and Mya arenaria) are common members of the estuarine benthic communities. This holds especially for the Elbe. Consequently it seems that the 'poorer' a community is, the more alien species can potentially establish.

Fourth argument: salt-tolerant freshwater alien species

In the analysis by Wolff (1999) the spatial distribution of alien species in the limnetic zones of Dutch estuaries as well as in inland waters was not taken into account. However, the specific introduction of alien species in freshwater areas are of considerable importance for the invasion of alien species in estuaries. In Germany the occurrence of alien species in inland waters is facilitated primarily by the shipping canals built during the last 
centuries (a.o. Dnieper-Bug Canal in 1784, RhineRhône Canal in 1834, Main-Danube Canal in 1992), which breached the natural barriers between distinct basins (Nehring 2005). In the macrozoobenthos of German inland waters 22 of the 44 established alien species were attributed to this introduction vector (S.Nehring, in press), seven of them occur in the Elbe (Table 1). Larval and postlarval drifting, transport on ships' hulls as well as active migration enabled these alien species to rapidly extend their distribution in the German waterways. The coastal waters of the North Sea are reached by inland water aliens first in the estuaries and salt-tolerant freshwater species can find adequate salinity conditions somewhere along the estuarine gradient. Since they can adapt to low salinities (e.g. the Pontocaspian zebra mussel Dreissena polymorpha and the amphipod Corophium curvispinum), four macrozoobenthic "freshwater" alien species, which were all introduced to inland waters first, have established permanent populations in inland waters as well as currently in the brackish part of the Elbe estuary (Table 1). It follows from this that the invasion of estuaries by alien species occurs not only via the ocean, but also through inland waters. This argument, very likely, is valid for Dutch waters too, but has not been proved yet (W.J. Wolff, personal communication 2005.01.29).

\section{Conclusion}

It seems that low indigenous species richness in aquatic communities facilitates invasions of 'new' species, but the frequency and intensity (or size) of inoculation are critical components in colonization success. The combination of brackish water unsaturated with ecological niches and with intensive international ship traffic has the highest potential infection rate for aquatic systems with alien macroinvertebrate species. In addition, estuaries are subjected to a two-sided invasion pressure by alien species through the ocean (mainly shipping) and through inland waters (mainly shipping canal construction). Further, due to their heavy exposure to interregional transports, estuaries with intensive international shipping have become important sources for the intraregional spreading of alien species (cf. Wasson et al. 2001).

Due to recent discussions on the development of an 'European Strategy on Invasive Alien Species' (EC Council 2004), an integration of the specific investigation criterion 'alien species' into aquatic observation programmes in combination with an appropriate adaptation of the monitoring strategy is recommended (Nehring and Klingenstein 2005). This optimization is essential to document new arrivals in an early phase, to determine their status and to assess the impacts and the invasiveness of alien species as well as the efficiency of eradication and control measures. On account of the given results, one should take into consideration to include the larger estuaries in an alien observation con- cept. This is an essential precondition for purposeful future activities in the field of the prevention and the management of alien species in European waters.

Acknowledgements The constructive and stimulating remarks of Karsten Reise, List and the helpful comments of an anonymous reviewer are greatly appreciated. The author gratefully acknowledges the permission of the Federal Institute for Hydrology in Koblenz for using unpublished data. I thank Wieland Schmitt, Koblenz and Thomas Meyer, Kiel for their assistance. The methods used in this survey comply with the current laws in Germany. The author acknowledges the support by the MARBEF Network of Excellence "Marine Biodiversity and Ecosystem Functioning" which is funded in the Community's Sixth Framework Programme (contract no. GOCE-CT-2003-505446). This publication is contribution number MPS-06008 of MarBEF.

\section{References}

ARGE Elbe (1991) Das oberflächennahe Zoobenthos der Elbe als Indikator für die Gewässerqualität. Wassergütestelle Elbe, Hamburg

ARGE Elbe (1994) Makrozoobenthon der Elbe: Arten, Biomasse und Güteklassifizierung zwischen Schmilka und Cuxhaven. Wassergütestelle Elbe, Hamburg

Arndt EA (1984) The ecological niche of Cordylophora caspia (Pallas, 1771). Limnologica 15:469-477

Caspers H (1959) Vorschläge einer Brackwassernomenklatur ("The Venice System"). Internat Rev ges Hydrobiol 44:313-315

CBD (1992) The Convention on Biological Diversity, UN Conference on Environment and Development, Rio de Janeiro. The Convention on Biological Diversity, http://www.biodiv.org

CBD (2000) Global strategy on invasive alien species. The Convention on Biological Diversity, UNEP/CBD/SBSTTA/6/INF/ 9:1-52

Cognetti G, Maltagliati F (2000) Biodiversity and adaptive mechanisms in brackish water fauna. Mar Pollut Bull 40:7-14

Cohen AN, Carlton JT (1998) Accelerating invasion rate in a highly invaded estuary. Science 279:555-558

Drake JA, Mooney HA, di Castri F, Groves RH, Kruger FJ, Rejmánek M, Williamson M (1989) Biological Invasions: A Global Perspective. Wiley, Chichester

EC Council (2004) European strategy on invasive alien species. Nature Environ 137:1-67

Gollasch S (1996) Untersuchungen des Arteintrages durch den internationalen Schiffsverkehr unter besonderer Berücksichtigung nichtheimischer Arten. Verlag Dr. Kovac, Hamburg

Gollasch S (2002) The importance of ship hull fouling as a vector of species introductions into the North Sea. Biofouling 18:105-121

IMO (2004) International convention for the control and management of ships' ballast water and sediments. International Maritime Organization, BWM/CONF/36:1-36

Leppäkoski E, Gollasch S, Olenin S (eds) (2002) Invasive aquatic species of Europe - distribution, impacts and management. Kluwer, Dordrecht

Michaelis H, Fock H, Grotjahn M, Post D (1992) The status of the intertidal zoobenthic brackish-water species in estuaries of the German Bight. Neth J Sea Res 30:201-207

Minchin D, Gollasch S (2003) Fouling and ships' hulls: how changing circumstances and spawning events may result in the spread of exotic species. Biofouling 19(Suppl):111-122

Nehring S (2002) Biological invasions into German waters: an evaluation of the importance of different human-mediated vectors for nonindigenous macrozoobenthic species. In: Leppäkoski E, Gollasch S, Olenin S (eds) Invasive aquatic species of Europe-Distribution, impacts and management. Kluwer, Dordrecht, pp 373-383

Nehring S (2005) International shipping-A risk for aquatic biodiversity in Germany. In: Nentwig W, Bacher S, Cock MJW, 
Dietz H, Gigon A, Wittenberg R (eds) Biological Invasions: From Ecology to Control. Neobiota 6:125-143

Nehring $\mathrm{S}$ (in press) Invasionen in limnischen und marinen Gewässern: Situation, Besonderheiten, Probleme, Lösungen. Naturschutz und Biologische Vielfalt

Nehring S, Klingenstein F (2005) Alien species in the Wadden Sea-A challenge to act. Wadden Sea Newsl 31:13-16

Nehring S, Leuchs H (1999) The BfG-Monitoring in the German North Sea estuaries: macrozoobenthos. Senckenbergiana marit 29(Suppl):107-111

Paavola M, Olenin S, Leppäkoski E (2005) Are invasive species most successful in habitats of low native species richness across European brackish water seas? Estuar Coast Shelf Sci 64:738-750

Petermeier A, Schöll F, Tittizer T (1996) Die ökologische und biologische Entwicklung der deutschen Elbe - Ein Literaturbericht. Lauterbornia 24:1-95

Reineking B (2005) Harbors and shipping. In: Essink K, Dettmann C, Farke H, Laursen K, Lüerßen G, Marencic H, Wiersinga W (eds) Wadden Sea Quality Status Report 2004. Wadden Sea Ecosystem 19:37-40

Reiners F (1997) Artenliste der Meeresstation Helgoland, Internet Version, update of the list given by J. Harms in 1993. www.awibremerhaven.de

Reise K, Gollasch S, Wolff WJ (2002) Introduced marine species of the North Sea coasts. In: Leppäkoski E, Gollasch S, Olenin S (eds) Invasive aquatic species of Europe - distribution, impacts and management. Kluwer, Dordrecht, pp 260-266

Remane A (1934) Die Brackwasserfauna. Verh dt zool Gesell 36:34-74

Remane A (1969) Wie erkennt man eine genuine Brackwasserart? Limnologica 7:9-21
Ruiz GM, Carlton JT, Grosholz ED, Hines AH (1997) Global invasions of marine and estuarine habitats by non-indigenous species: Mechanisms, extent, and consequences. Amer Zool 37:621-632

Sandlund OT, Schei PJ, Viken A (eds) (1999) Invasive species and biodiversity management. Kluwer, Dordrecht

Schöll F, Fuksa J (2000) Das Makrozoobenthos der Elbe vom Riesengebirge bis Cuxhaven. Bundesanstalt für Gewässerkunde, Koblenz

Smith LD, Wonham MJ, McCann LD, Ruiz GM, Hines AH, Carlton JT (1999) Invasion pressure to a ballast-flooded estuary and an assessment of inoculant survival. Biol Invasions 1:67-87

Tittizer T, Schöll F, Schleuter A, Schleuter M (1988) Einsatz von Taucherschacht und Taucherglocke bei benthosbiologischen Untersuchungen. Dt Gewässerk Mitt 32:141-144

Tittizer T, Schöll F, Banning M, Haybach A, Schleuter M (2000) Aquatische Neozoen im Makrozoobenthos der Binnenwasserstraßen Deutschlands. Lauterbornia 39:1-72

Wasson K, Zabin CJ, Bedinger L, Diaz MC, Pearse JS (2001) Biological invasions of estuaries without international shipping: the importance of intraregional transport. Biol Conserv 102:143-153

Wolff WJ (1999) Exotic invaders of the meso-oligohaline zone of estuaries in the Netherlands: why are there so many? Helgol Meeresunters 52:393-400

WWF (2001) Performance of biocide-free antifouling paints. Trails on deep-sea going vessels, Vol I: Application of test paints and inspections of 2000. World Wide Fund For Nature Germany, Frankfurt/M Bremen 